\title{
LEARNING FROM THE PAST: USING ORIGINAL TECHNIQUES TO CONSERVE A TWELFTH-CENTURY ILLUMINATED MANUSCRIPT AND ITS SIXTEENTH- CENTURY GREEK-STYLE BINDING AT THE MONASTERY OF ST CATHERINE, SINAI
}

\author{
Andrew Honey and Nicholas Pickwoad
}

\begin{abstract}
This paper describes the conservation treatment at the Monastery of St Catherine, Sinai of an illuminated manuscript preserved in an important but severely damaged sixteenth-century Greek-style Sinai binding. The conservation treatment aimed to restore functionality to this binding with minimum intervention enabling the important manuscript to travel to an exhibition. The repair techniques evolved during treatment as the two conservators studied and used the techniques of the original binder. The repair included the partial in situ re-sewing of the manuscript, working around and supplementing the original sewing, and reattaching the wooden bookboards. The primary endbands were repaired to preserve and support the unique secondary metal-thread endbands and a new method was devised to repair an interlaced clasp-strap. The planning, as well as the working methods and techniques described, highlight new avenues both for the conservation of Byzantine manuscripts and for future conservation at this important library.
\end{abstract}

ÖZET

Bu yazı, Sina Azize Katerina Manastırı'ndaki, bir tezhipli elyazmasının konservasyon çalışmalarını anlatmaktadır. Kitap, ciddi hasar görmüş ama önemli bir 16. yüzyıl Yunan tarzı Sina cildine sahiptir. Konservasyonun amacı bu cildin en az müdahaleyle işlevini tekrar kazanması ve böylece yazmanın bir sergiye yollanabilmesiydi. İki konservatör, kitabın mücellidinin tekniklerini inceleyip kullanırken onarım teknikleri de geliştirdiler. Onarım yazmanın kısmi in situ yeniden dikimini (özgün dikişin çevresinde çalıșılıp desteklenmesi) ve cilt kapaklarına yeniden tutturulmasını kapsıyordu. Temel şirazeler korunarak onarıldı ve ikincil metal iplikli şirazelere destek oluşturuldu. İç içe geçen örgü şiraze onarımı için yeni bir yöntem geliştirildi. Anlatılan planlama ve çalışma yöntemleri hem Bizans yazmalarının konservasyonu hem de gelecekte bu önemli kütüphanedeki konservasyon çalışmaları için tutulacak yeni yolların altını çizmektedir.

\section{INTRODUCTION TO SINAI, MS. GREEK 418 AND THE HEAVENLY LADDER}

The Heavenly Ladder, written in the seventh century AD by John Climacus, is a treatise on monastic virtues consisting of thirty chapters conceived as rungs of a ladder reaching from earth to heaven. The work was designed for the monks of Raitho, the present day El-Tur on the Red Sea coast of the Sinai peninsula, but found a much wider audience in Greek monastic communities and became "the most widely read of all ascetic writing" $[1$, p. 6]. John Climacus (before AD 579-c. 650) was a Sinai hermit before becoming abbot of the Monastery of St Catherine, Sinai and the Monastery, where the work was written, preserves in its library one of the most richly illustrated manuscripts of the Heavenly Ladder. MS. Greek 418, a twelfth-century AD illuminated parchment manuscript of 313 leaves, has 43 miniatures illustrating the prefatory material and the 30 chapters or homilies on spiritual exercises for the monks. For detailed information of the manuscript with illustrations of all the illuminations and earlier bibliographies see Martin, and Weitzmann and Galavaris $[1,2]$, for the Monastery and its library see Nelson and Collins, and Manafis [3, 4]. Although the provenance of the manuscript is not known, Martin (and his view repeated by later writers), thought that the manuscript was produced in "a region near Palestine, perhaps actually at Sinai" [1, p. 187]. The sumptuous manuscript is preserved in an equally lavish and rare blindtooled, Greek-style binding; it is covered with a fine-quality red tanned-goatskin, has silver furniture and elaborate secondary endbands of silver and silver-gilt metal threads, Fig. 1. Weitzman and Galavaris dated the binding to "the second half of the

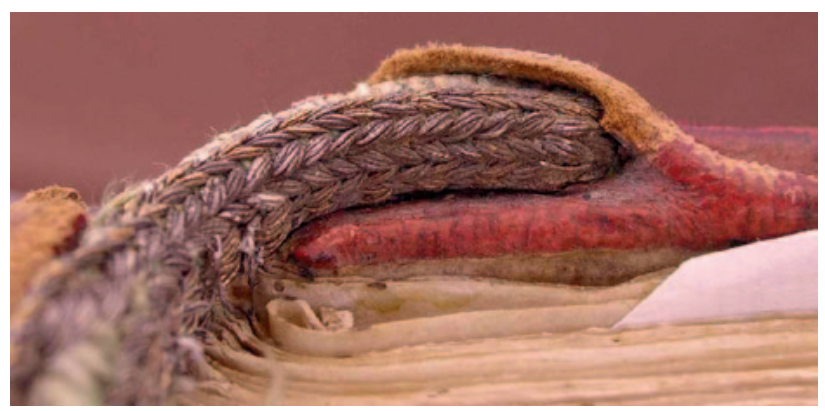

Fig. 1 Detail of a portion of the intact decorative metal-thread secondary endband before treatment (right or lower board, head).

fourteenth century" [2, p. 153] and Boudalis to the fifteenth century "possibly in Constantinople" [5, p. 32], but recent work by Sarris has now firmly placed this binding in a group of nine manuscripts bound at the Monastery in the late sixteenth century $\mathrm{AD}[6]$. The quality of the binding of this manuscript is unsurpassed by any other bound at the Monastery and is of great importance. The binding has an unsupported sewing structure, using four stations, with wooden boards attached to the sewn bookblock by means of sewing thread only; a textile spine lining extending onto the outer face of the boards; endbands sewn to the bookblock and the head and tail edges of the boards; and metal bosses and triple interlaced leather clasp-straps laced through the right board with metal rings that fit over edge pins on the left board. For an overview of Greek-style bookbinding with bibliographies of the earlier literature see Federici and Houlis [7] and Szirmai [8], for the unique all metal-thread endbands see Boudalis [5], and for a glossary of bookbinding terms see Ligatus [9].

\section{INTRODUCTION TO THE CONSERVATION}

MS. Greek 418 with its miniatures documenting monastic life was requested by the Getty Museum in 2005 to travel to Los Angeles as part of their exhibition in 2006-7: 'Holy Image, Hallowed Ground: Icons from Sinai' [3]. Although the importance of this manuscript to the planned exhibition was clear, the condition of the manuscript was alarming when viewed in May 2005 by Nicholas Pickwoad, Fig. 2. The text leaves survive in excellent condition and have been described as such in print [2, p. 153], but the binding was very damaged and the unique secondary endbands were now very vulnerable, Fig. 3.

The sewing structure was broken down along the left joint and the damage extended across the bookblock at sewing station one. The sewn connection of the bookblock to the boards was completely broken and both the spine lining and covering leather were completely split along both joints. The head and tail endband cores were broken at, or near, the joints and both wooden boards were now only attached to the bookblock by the elaborate, secondary endband sewing in silver and silver-gilt metal threads. In addition, these elaborate secondary endbands were partially detached from the primary endband cores. The binding retained both of its triple interlaced leather clasp-straps but two of the strands of the lower strap were broken at the 


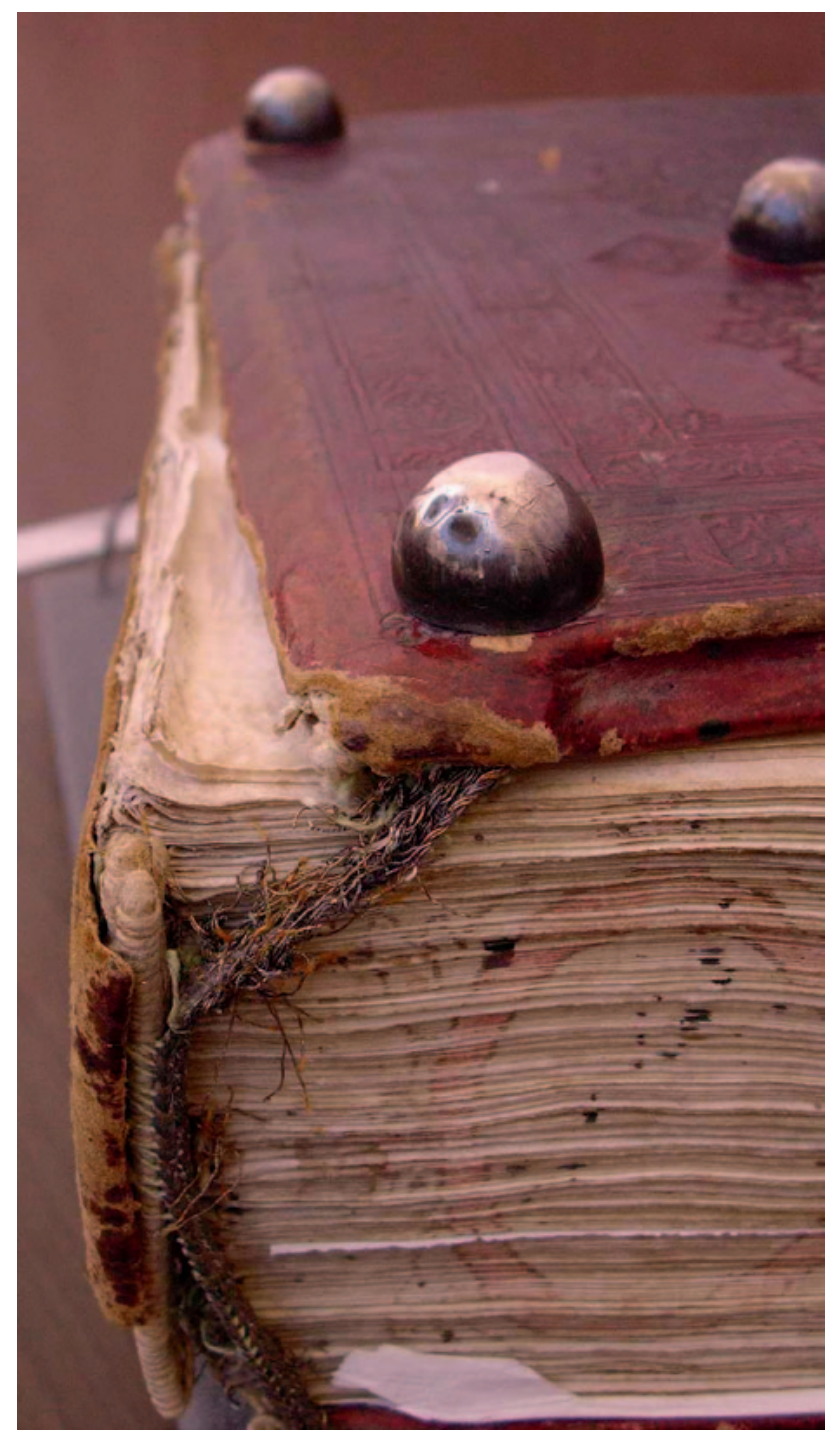

Fig. 2 Manuscript and binding before treatment, left or upper board detached and showing stretched secondary endband sewing.

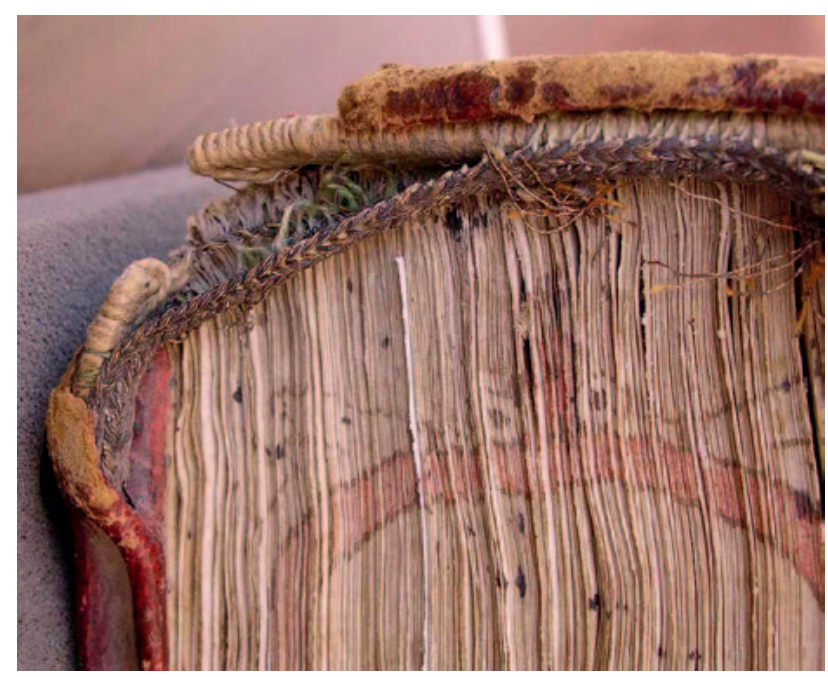

Fig. 3 Head endband, left or upper joint before treatment showing broken endband cores and partially detached secondary endband.

exterior face of the board, making this rare surviving clasp with its cast silver stirrup-ring vulnerable. Any further strain placed on the binding in this state would result in irremediable damage to the binding of this important manuscript.
The authors had been involved with a preservation project to "secure the future of the [Monastery's] library" [10, p. 33] begun in 1998 and jointly organised by the Saint Catherine Foundation and the University of the Arts, London. This project has concentrated to date on a condition survey of the bound manuscripts and early printed books coinciding with planning work to box and rehouse the manuscripts, remodel the library and provide the Monastery with modern conservation workshops. An opportunity to carry out a conservation treatment at the Monastery, although daunting, was welcomed as it would highlight the requirements of the future workshop, aid its planning and would allow the project to demonstrate its conservation abilities to the monastic community.

Conservation work carried out by the project prior to this had been limited to minor work required for the safe display of the Achtiname within the Monastery, and emergency work to record and safely remove a number of manuscript fragments uncovered during building work [11]. The Monastery did not have suitable conservation facilities in which to carry out detailed and complex treatments but a converted cell, which had previously been used for some work in caring for the collection, potentially offered a location for emergency work. Unlike other conservation disciplines, the treatment of books and manuscripts is not usually site or time specific and is usually undertaken by a sole conservator. The treatment of this manuscript would require a different approach for its planning and new methods of work.

\section{THE PROPOSED TREATMENT}

The manuscript had been surveyed in November 2003 and Nicholas Pickwoad made further notes and took additional digital photographs during his 2005 trip to supplement the existing slide photographs, drawings and survey forms. The authors discussed possible treatments with Christopher Clarkson and a treatment proposal was submitted to the Synaxis of the Monastery in December 2005, with the treatment planned to be completed in a single week during spring 2006.

The treatment proposal sought to address four main areas of damage, to restore functionality to the binding and to enable the manuscript to travel safely. The treatments were designed so that they could be carried out in a temporary ad hoc workshop with all the tools and materials required taken to the Monastery. The proposed treatment aimed to secure the broken sewing structure with new thread and reconstitute the primary, sewn board attachment, to secure the broken endband cores where they had pulled away from the bookblock, to reattach the secondary endband sewing to the repaired primary-sewn endbands and to reattach the partly broken interlaced clasp-strap.

Planning of the work before the trip needed to be thorough and although the broad aims of the treatment had been agreed, exact methods to achieve them would need to be flexible and to be refined during the work. A wide range of tools and materials were packed to allow for all eventualities. The timetable for the work was both fixed and tight and the project was planned to allow the maximum contact time with the manuscript.

Although both authors have experience of conserving western manuscripts, the in situ repair of Greek-style sewing and endband structures was unfamiliar and would require new approaches. Building on the success of the survey method used at the Monastery, the treatment was to be undertaken jointly by two conservators [10, p. 37]. It was envisaged that this would generate a 'dialogue' between the conservators in relation to the manuscript, encouraging each conservator to continually comment on what they saw and what they planned to do. This would speed up the decision-making process and expedite the assessment of treatment ideas. Documentation would use a combination of digital photography and a written work diary to 


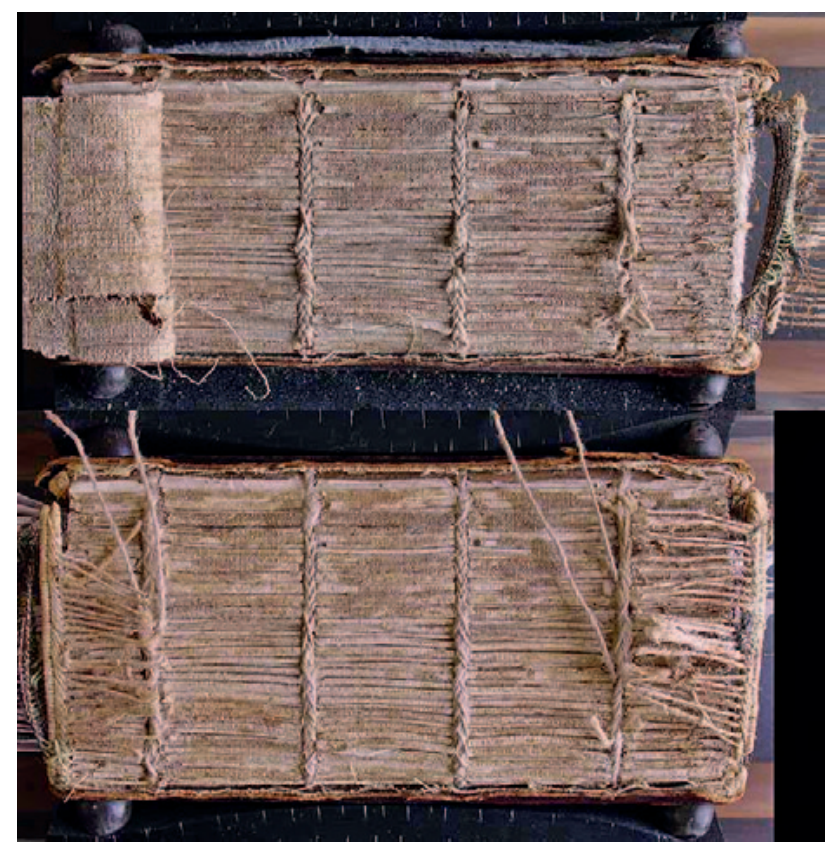

Fig. 4 Partially removed textile spine lining showing damaged sewing and sewn board attachment (above). Completed repaired sewing and sewn board attachment (below).

record work in progress, minimising the time taken, while also providing maximum information for a final report on return from the Monastery.

\section{REPAIR OF SEWING AND SEWN BOARD ATTACHMENT}

This Greek-style binding has an unsupported sewing structure, using four stations, with its wooden boards originally attached to the sewn bookblock by means of sewing thread only. This is unlike a Western binding structure where the boards are attached to the bookblock with sewing supports and repair techniques would need to take this into account. Before treatment began, the spine leather was lifted dry from the underlying textile lining and retained. The textile spine lining was lifted dry from the spine between stations one and four, the broken external headband tiedowns were pulled clear of the lining and the lining was peeled away from the head, Fig. 4. The internal tiedowns, with three exceptions only, were all broken under the lower endband core and these were cut to allow access. The textile spine lining was removed (and retained), revealing the spine of the manuscript with the damaged endbands peeled back though still attached to the boards. The covering leather was lifted along the back edge of the boards and the textile lining was separated from the leather. This exposed the bridling stations, with remains of the text-block sewing thread in stations one and four on the right board, and at all stations on the left board. It became clear that two threads had been looped under the bridles at each station.

The removal of the spine liner and leather exposed the spine and broken sewing and a great deal of animal glue was also revealed across the spine at the head within the area covered by the endband tiedowns and towards the front joint at the tail. It would appear that this was the result of an earlier repair. The adhesive residue, the repair glue and the remains of the leather on the spine were softened with starch paste and removed mechanically.

Although the sewing structure was broken down along the left joint and the damage extended across the bookblock at sewing station one, and the sewn connection of the bookblock to both boards was completely broken, the newly revealed spine showed that away from these areas of damage the sewing appeared to be sound. Studying the original structure indicated that it might be

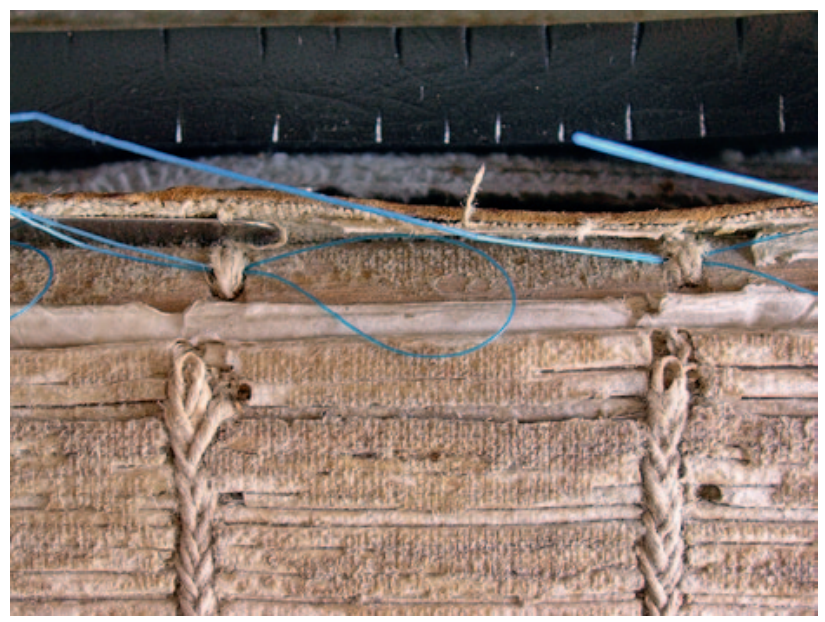

Fig. 5 Insertion of floss threaders under bridles on the back edge of the right or lower board.

'patched' by replicating the original sewing technique. Before this began the broken sewing threads were removed from the intact bridles on the right joint. These bridles were then prepared to accept the replacement sewing by lacing flexible floss threaders under the bridles on the outside of the board, lacing them from head to tail, Fig. 5. Floss threaders are flexible polyester needles with large eyes designed to thread dental floss under braces and allowed access to these tight bridles without breaking them [12].

The final four gatherings were then re-sewn with linen seaming twine. As the thread used to sew the endleaf bifolium to the board was pulled under each bridle, a second floss threader was also pulled under the bridles to allow the thread from the final text quire to be pulled under the bridle as well (in the opposite direction). This process essentially repeated the original sewing, an all-along two-step linkstitch, picking up the loops from the original sewing at each station where the new sewing met the original, intact sewing. Wherever possible, the original sewing thread was preserved in place, but any detached threads were removed and retained. The ends of the new sewing thread were secured by winding them in a helix around station four. The same process was repeated along the left joint, sewing the endleaves and the first seven quires all-along, using a two-step linkstitch. Quires 8-16 were sewn only between stations one and two, quires 17-20 were sewn at all stations, and quires $21-28$ between stations one and two only, Fig. 4.

It was remarkable how replacing the sewing and catching up the original 'links' in the chain drew the spine back into shape and pulled the head edge of the textblock together, which had spread when the left half of chain one had broken down. It became evident that unsupported structures can be 'patched' in a way that Western structures with broken sewing supports seldom allow, leaving all the intact original structural elements in place, and replacing only those that are damaged or missing. It is a versatile and adaptable method.

With the sewing and sewn board attachment repaired, the spine was manipulated into a continuous, comfortable, even round and placed in a press. The loose ends of new sewing thread were frayed out and pasted to the spine, together with loose original threads. The repaired sewing chains were dampened with paste and flattened with a bone folder. The spine was pasted and left for a short while to soften the spine folds, which were then gently flattened with bone folders. A release layer of hand-made Japanese tissue was pasted to the spine and a new linen-textile spine-lining was then pasted to the spine and back edges of the boards. 


\section{PRIMARY ENDBAND REPAIRS}

Although the sewing and sewn board attachment had been successfully repaired, the condition of the primary endbands was still of great concern. Greek-style primary endbands have an important structural function, adding to board attachment and helping to control the opening of the manuscript [5, p. 30]. In addition, the unique but severely damaged decorative metalthread secondary endbands could only be preserved if the structural function of the damaged primary endband to which they were still attached was restored. The head endband cores were broken at both joints and the tail endband cores at one joint. However, the endband cores were still firmly attached to the boards where they were covered by the elaborate secondary endbands and the head cap of the covering leather, Figs 1 and 3. The primary endbands would require in situ treatment to repair the broken cores and provide attachment at every quire of the textblock if they were to regain their structural function and provide a sound support for the decorative secondary endbands.

The repairs began with the tail endband. Borrowing a technique used by the original binder to join the two halves of the sewn bookblock, the broken ends of the tailband core at the right joint were 'bridled' with three turns of linen thread. Staggered horizontal loops of thread were taken between the cores on each side of the break, pulling these together to close the gap between the broken ends of the cores and then binding them to the lower core by wrapping the thread around the lower core. A small piece of goat parchment was prepared to bridge the break in the endband cores, cut to the height of the cores and bevelled along all edges to give thin, flexible edges that could be wrapped over the cores. The parchment strip was bound to the back of the cores with the same thread, using a small, tightly-curved, blunt needle, starting from the board in a packed, wrapping movement of the thread around both cores with occasional figure-of-eight stitches penetrating the parchment to prevent slippage along the cores. The loose ends of thread from the bridling and the start of the wrapping were included within this sewing, along the back of the parchment to further reinforce the break, Fig. 6. The packed wrapping continued for about $20 \mathrm{~mm}$ from the point of the break across the textblock, making tiedowns in a figureof-eight pattern at the centre of each quire. The new thread was taken between the cores to make a figure-of-eight path around the lower core and through the textblock. On emerging from the spine, the thread was taken under the lower core to the front of the endband, and then between the cores to emerge at the back where it was taken across the back of the lower core at an angle, reflecting the angled lower-core sewing of the original endband, it was then taken under the lower core at the centre of the next quire to form the next internal tiedown, emerging below the lowest main-sewing chain-stitch to repeat the process until the detached core was firmly reattached to the textblock.

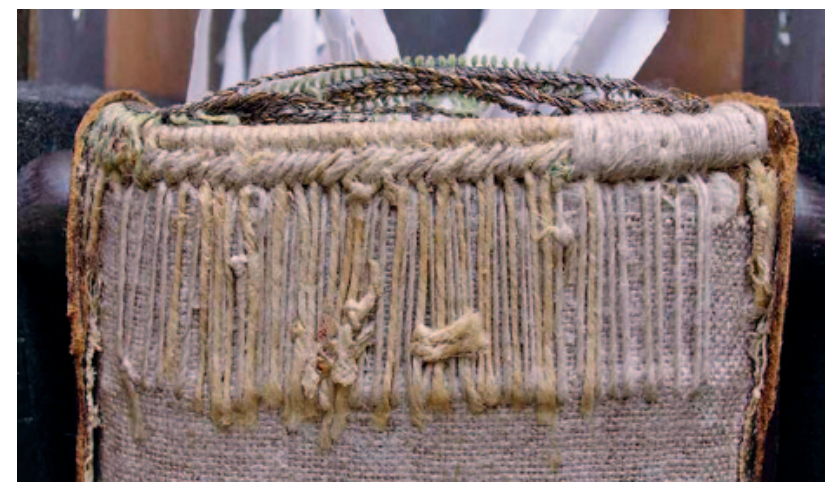

Fig. 6 Completed repaired and re-sewn tail primary endband.

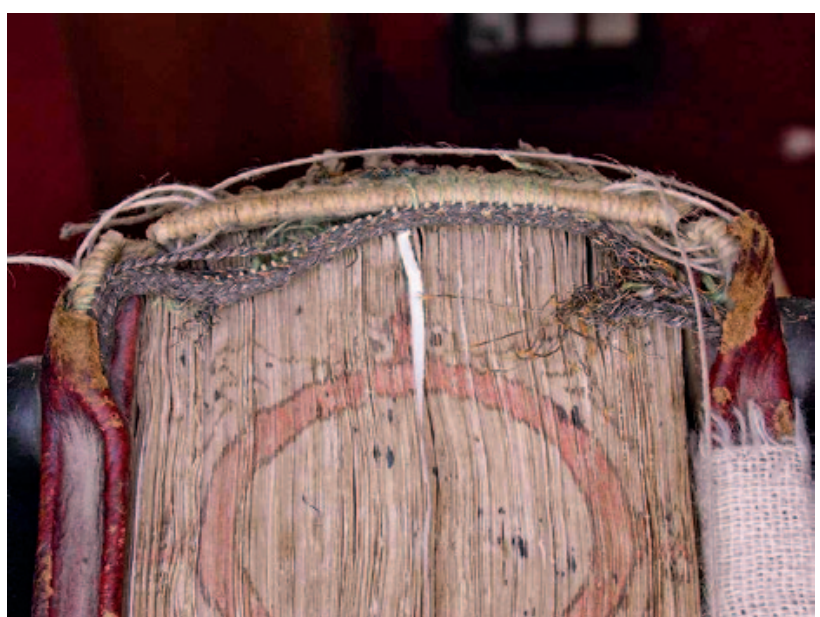

Fig. 7 Continuous bridling repairs used to bridge breaks in head endband cores at both joints.

The repair and reattachment of this endband had a marked effect on the opening characteristics of the tail end of the spine, which now opened in a more controlled manner than the unrepaired head. It noticeably improved board-leverage on the textblock when the board was opened, something that the thread-only attachment of the boards to the sewing structure did not produce. It underlined the structural importance of these endbands within the Byzantine/Greek binding tradition.

The head endband was then repaired with the same technique. However, as the head endband cores were broken at both joints, the staggered bridling technique was refined to link the repairs across the spine with a continuous thread, giving extra support to the repair, Fig. 7.

\section{SECONDARY ENDBAND REPAIRS}

The original treatment proposal had suggested that the metal threads of the secondary endband could be reattached to the repaired primary endbands by replacing their broken green silk warp threads with a new fine linen thread. However, the time that remained within the planned schedule did not allow for this complex reconstruction of the secondary sewing. The decision was therefore taken to temporarily secure the metal thread to the repaired primary-sewn endband cores with simple individual tackets of linen thread. The plied metal threads forming the separate rows were first aligned, and where possible pushed closer together on the green silk warp threads to form a compact endband once more. Individual thread tackets were then loosely tied over the secondary endband around the primary cores with a very fine linen thread to hold these in place. These were worked from where the endband was most intact, continuing towards the unravelled areas and aligning the endband in the process, at about $5 \mathrm{~mm}$ intervals. Once all the tackets were in place, the volume was gently opened to check that the inevitable flexing of the primary cores did not strain the secondary endband that was now secured. The tackets were then tightened and knotted to hold the secondary endband whilst allowing for some movement. The loose ends of thread were cut and each tacket was turned to move the knot beneath the lower primary core, Fig. 8.

\section{REPAIRS OF THE INTERLACED CLASP-STRAP}

The binding retained both of its triple interlaced leather foreedge clasp-straps, but two of the strands of the lower strap were broken at the exterior face of the board. It is rare for these clasps to survive, and increased handling in preparation for the exhibition put the strap at risk. To make the broken clasp-strap 


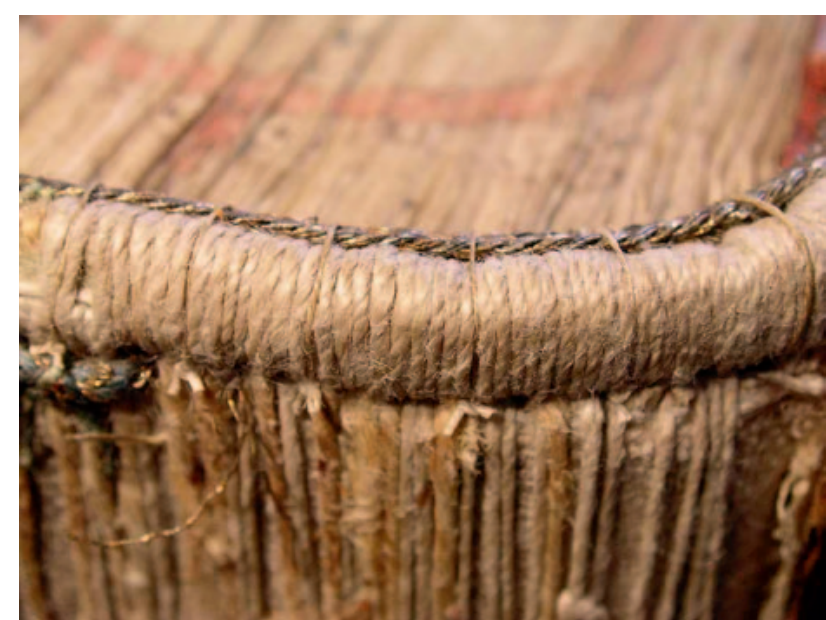

Fig. 8 Repaired head primary endband from back with tackets used to secure secondary endband.

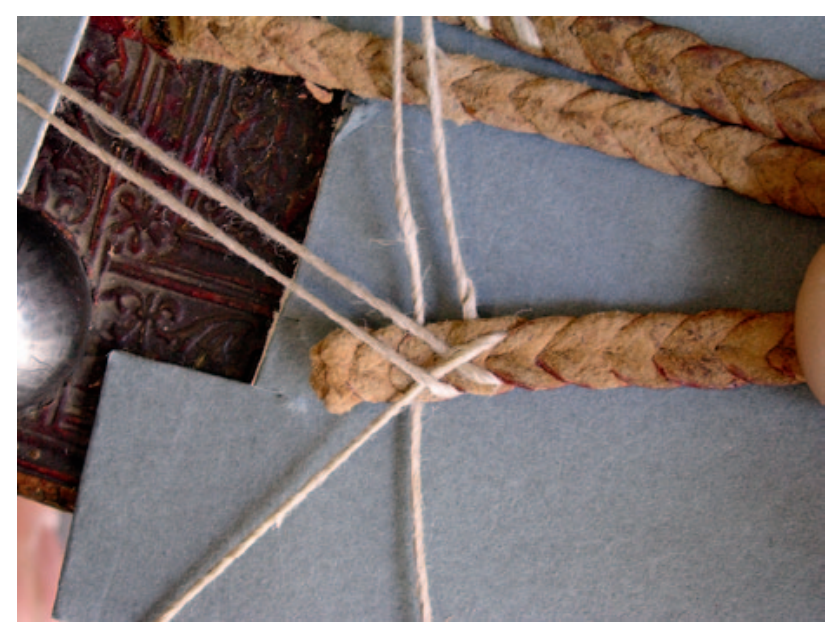

Fig. 9 Broken clasp strap, plaiting new threads to provide an extension

secure a repair was required that would bridge the break and make it functional.

For both of the broken strands a blunt needle was inserted just above the fourth interlace point from the break, under the upper of the two straps which form each element of the triple strap. A thin linen thread was pulled through the strap and wrapped around the edges of the strap under the chevron which is formed by the interlace technique, so that it could not be seen on the outer surface, Fig. 9. This was repeated twice and the resulting six threads were then plaited together on the reverse of the strap to give a tail. The broken end of the strap was whipped to the new plait with a fine linen thread. The new plaits attached to the broken interlace strap were then pulled through the existing holes in the board in front of, and beneath, the broken strap stubs and tied inside, Fig. 10. The loose ends of the new thread were frayed out and pasted under the lifted edges of the parchment.

\section{CONCLUSIONS}

The treatment allowed the manuscript to travel safely to its exhibition, but it is not finished. The tight timescale and absence of a conservation workshop precluded some types of work and this will need to be completed when the new workshop is built. Work to reconstitute the secondary endbands remains to be done and the manuscript requires a leather re-back, with the original spine either mounted on this spine or housed separately.

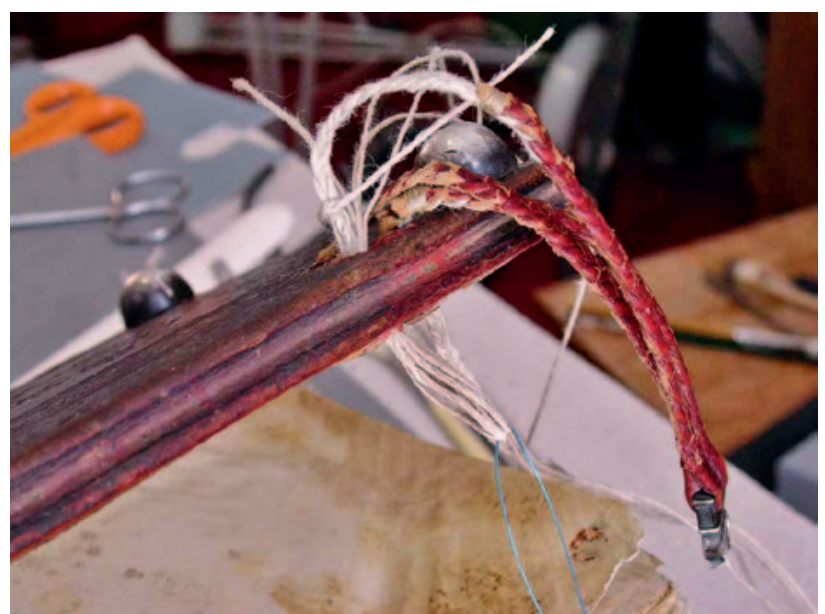

Fig. 10 Pulling the plaited thread extension through a lacing hole with a floss threader.

This work proved to be challenging for the authors - but also rewarding. The close study of the structure of Greek-style bindings carried out as part of the condition survey of the Monastery's manuscripts as well as the direct observation of this manuscript provided models upon which these repairs were based. The in situ repair of the sewing, sewn board attachment and primary endbands was accomplished using techniques adapted from those used by the original binder and the ability to repair selected parts of damaged structures within Greekstyle bindings is a new and exciting avenue for conservators more accustomed to western binding structures. This successful treatment, carried out in less than ideal surroundings, also shows possible approaches that will be useful for the future planning, scheduling and execution of conservation in this important collection. The use of digital photography, work diaries, and the collaboration of a team of two conservators have all proved to be a useful approach to maximising conservation impact with limited time available, while dealing with a remote desert location.

\section{ACKNOWLEDGEMENTS}

All photographs are by permission of the Holy Synaxis of the Monastery of St Catherine, Sinai and Ligatus Research Unit, University of Arts, London. The authors would like to thank Nancy Turner (Conservator, J. Paul Getty Museum, Los Angeles) who read and commented on a draft of this paper. Deborah Evetts (Private Conservator, Connecticut) discovered the value of floss threaders for book conservation and their suggestion for the treatment described here came from Chris Clarkson.

\section{REFERENCES}

1 Martin, J.R., The Illustrations of the Heavenly Ladder of John Climacus, Studies in Manuscript Illumination V, Princeton University Press, Princeton NJ (1954).

2 Weitzmann, K. and Galavaris, G., The Monastery of Saint Catherine at Mount Sinai. The Illuminated Greek Manuscripts. Vol. 1: From the Ninth to the Twelfth Century, Princeton University Press, Princeton NJ (1990).

3 Nelson, R.S. and Collins, K., Holy Image, Hallowed Ground: Icons From Sinai, Getty Publications, Los Angeles (2006).

4 Manafis, K.A. (ed.), Sinai: Treasures of the Monastery of Saint Catherine, Ekdotike Athenon, Athens (1990).

5 Boudalis, G., 'Endbands in Greek-style bindings', The Paper Conservator 31 (2007) 29-49.

6 Sarris, N., Classification of Finishing Tools in Byzantine/Greek Bookbinding: Establishing Links for Manuscripts from the Library of the St. Catherine's Monastery in Sinai, Egypt, PhD dissertation, Camberwell College of Arts, University of the Arts, London (forthcoming).

7 Federici, C. and Houlis, K., Legature Bizantine Vaticane, Istituto Centrale per la Patologia del Libro, Rome (1988). 
8 Szirmai, J.A., The Archaeology of Medieval Bookbinding, Ashgate, Aldershot (1999) 62-92.

9 Ligatus Research Unit, 'An English/Greek terminology for the structures and materials of Byzantine and Greek bookbinding', http://www.ligatus.org.uk/glossary (accessed 8 January 2010).

10 Pickwoad, N., 'The condition survey of the manuscripts in the monastery of Saint Catherine on Mount Sinai', The Paper Conservator 28 (2004) 33-61.

11 Pickwoad, N., McAusland, J. and Kalligerou, M., 'The Cell 31A project', http://www.ligatus.org.uk/stcatherines/sites/ligatus.org. uk.stcatherines/files/cell31A.pdf (accessed 7 August 2009).

12 Clarkson, C., private conservator, Oxford, personal communication, November 2005 .

\section{AUTHORS}

Andrew Honey is a book conservator at the Bodleian Library in Oxford. He graduated from Camberwell College of Arts in 1994 with a BA (Hons) in Paper Conservation and studied the conservation of rare books and manuscripts at West Dean College under Christopher Clarkson from 1995-1997. He has been a visiting research fellow at the Ligatus Research Unit, University of the Arts London since 2005 working for the Saint Catherine's Monastery Library Project. Address: Bodleian Library, Broad Street, Oxford, OX1 3BG, UK. UK. Email: andrew. honey@bodleian.ox.ac.uk

Professor Nicholas Pickwoad is the director of the Ligatus Research Unit, University of the Arts London and project leader of the Saint Catherine's Monastery Library Project. After gaining a doctorate at Oxford University he trained with Roger Powell and has been advisor on book conservation to the National Trust from 1978. He was editor of volumes 8-13 of The Paper Conservator, taught book conservation at Columbia University, New York from 1989-1992 and was chief conservator in the Harvard University Library from 1992-1995. He teaches courses in Europe, Australia and America on the history of European bookbinding. In 2009 he was awarded the Royal Warrant Holder Association's Plowden Medal. Address: Ligatus Research Unit, The University of the Arts London, Wilson Road, London, SE5 8LU, UK. Email: npickwoad@paston.co.uk 